\title{
エビデンスに基づくリスク・ベネフィットのコミュニケーション： SDM〈共有意思決定に向けて〉
}

\author{
中山健夫
}

\section{Evidence-based Risk and Benefit Communication for Shared Decision Making}

\author{
Takeo Nakayama \\ Department of Health Informatics, School of Public Health and Graduate School of \\ Medicine, Kyoto University; Yoshida Konoe-cho, Sakyo-ku, Kyoto 606-8501, Japan.
}

(Received August 4, 2017)

\begin{abstract}
Evidence-based medicine (EBM) can be defined as "the integration of the best research evidence with clinical expertise and a patient's unique values and circumstances". However, even with the best research evidence, many uncertainties can make clinical decisions difficult. As the social requirement of respecting patient values and preferences has been increasingly recognized, shared decision making (SDM) and consensus development between patients and clinicians have attracted attention. SDM is a process by which patients and clinicians make decisions and arrive at a consensus through interactive conversations and communications. During the process of SDM, patients and clinicians share information with each other on the goals they hope to achieve and responsibilities in meeting those goals. From the clinician's standpoint, information regarding the benefits and risks of potential treatment options based on current evidence and professional experience is provided to patients. From the patient's standpoint, information on personal values, preferences, and social roles is provided to clinicians. SDM is a sort of "wisdom" in the context of making autonomous decisions in uncertain, difficult situations through interactions and cooperation between patients and clinicians. Joint development of EBM and SDM will help facilitate patient-clinician relationships and improve the quality of healthcare.
\end{abstract}

Key words_— shared decision making; evidence-based medicine; clinical practice guideline; communication

\section{EBM の誕生と発展}

今日の臨床医療の基盤とも言える根拠に基づく医 療 (evidence-based medicine; EBM) は, 1991 年, カナダの臨床疫学者・Guyatt の提唱によって誕生 した. ${ }^{1)} \mathrm{EBM}$ は多くの臨床家の関心と社会的な意識 の高まりとともに多様な分野で普及し，現在はより 広くエビデンスに基づく臨床実践（Evidence-based practice）とも呼ばれている. EBM は「臨床家の勘 や経験ではなくエビデンスを重視して行う医療」と 言われる場合があるが，本来の EBM は，「臨床研 究によるエビデンス, 医療者の熟練・専門性, 患者 の価值観・希望，そして患者の臨床的状況・環境を 統合し，よりよい患者ケアのための意思決定を行う もの」とされている. ${ }^{2)}$ 臨床家の経験を軽視して研

京都大学大学院医学研究科社会健康医学系専攻健康情 報学分野（干606-8501 京都市左京区吉田近衛町）

e-mail: nakayama.takeo.4a@kyoto-u.ac.jp

本総説は, 日本薬学会第 137 年会シンポジウムS29 で

発表した内容を中心に記述したものである.
究によるエビデンスばかりを偏重することは，この 定義に立ち戻れば誤解であることが分かる。 EBM の主導者の一人である Sackett らは，1996 年の $\mathrm{BMJ}$ 誌で「EBM とは個々の患者のケアに関する意 思決定過程に, 現在得られる最良の根拠（current best evidence) を良心的 (conscientious)，明示的 (explicit)，かつ思慮深く（judicious）用いること」 であると述べ, 3$)$ ランダム化比較試験の絶対視や, 患者の多様性・個別性を尊重しない cook-book 的 な扱いに警鐘を鳴らしている.

2. Shared decision making (SDM) とは何か?

医療において患者の価值観を尊重する社会的要請 の高まりと EBM の普及を背景に，臨床的な意思決 定，そして患者と医療者の合意形成の手法として， 近年, Shared decision making (SDM) が注目され ている. ${ }^{4-6)}$ SDM は日本語で協働的意思決定, 患者 参加型医療，共有意思決定などとされるが，まだ定 訳はない。臨床の場面では，「患者は医療者, 特に 医師の指示に従えばよい」という伝統的な医療者の 
父権主義（パターナリズム）が根強く存在するのと 同時に，近年では「患者のことを最も知っているの は患者であり, 決めるのは情報を得た患者自身であ る」という一種の消費者主義（コンシューマーリズ 厶）も力を得つつある.SDM は父権主義と消費者 主義の対立的な関係を解き，患者と医療者の協働と 問題解決を目指す新たな調和的アプローチと言え る. ${ }^{7)}$

医療の場において，患者と医療者は立ち位置と視 点が本質的に異なり，共通するのは同じ制度の下 で，同じ場所で，同じ病気に向き合っている点だけ とも言える，何を目指して治療を行うか，治療の目 標という基本的な方向性すら，両者の関係の初期に はかならずしも共有されていない。患者と医療者 は，それぞれの情報を相手に伝え，相手から受け取 り，そのやり取りを繰り返す。その過程で臨床的に 実現可能で，患者自身も受け入れることのできる目 標が共有され，それに向けて治療法が選択されて， 目標の実現に向けて協働を進めていく，その過程の 中で，医療者も患者も，それぞれの形で責任を共有 することになる，これまでの患者は，医療における 様々な選択に際して，かならずしも自律的な意思決 定ができなかったが，共有決定の普及とともに，そ のような場面に出会うことが多くなるであろう。患 者の自己決定の拡大は，社会から好意的に受けとめ られるが，同時に患者の抱える葛藤や責任は重くな ることも予想される。しかし最終決定を患者が行っ たとしても，医療者はその全責任を患者に預けるこ とはできない.1つの意思決定に患者と医療者がと もに係わり，その責任を分かち合うことは，共有決 定の大切な要件となるであろう。すなわち，SDM において「共有」すべきものは，「(双方の）情報・ 目標・責任」となる。そして，これらの共有を進め るために医療者と患者・家族の間で十分なコミュニ ケーションが必要とされる。コミュニケーション は，双方向性・交互作用があり，動的 (dynamic), すなわち時間とともに変化するプロセスという特性 を持つ.このようなコミュニケーションに際して医 療者は患者に対し，価伹観の尊重，葛藤への共感， 必要な時間を待ち, リスクの認知と自分の価值観を 擦り合わせていく過程の支援などが求められるであ ろう. ${ }^{8)}$ 医師が診断結果と選択肢を一方的に患者や 家族に預けて意思決定を求めることは，SDM と似
て非なる行為と言える.SDM の実践・研究は海外 では非常に活発化しており，多くの研究報告がなさ れてきた隣接する概念であるインフォームドコンセ ント（informed consent; IC）の論文数を 2016 年に は超えている。一方，国内の SDM の研究・実践に 関する報告は極めて少なく，まさに今後の発展が強 く期待される課題と言える.

\section{EBM の実践における SDM の重要性}

EBM の実践は医療者が主体であり，SDM は医 療者と患者の両方を主体とする概念であるが，とも によりよい意思決定を目指すもので，その過程，留 意点など多くを共有している，不確実性が高い，し かし決断を下さなければならない状況に置かれたと き，医療者と患者は，立ち位置と視点は異なるが， 何をしたらよいか分からず，心の中で困惑している ことは同じである。そこでできることは，相手と協 力して，その状況にともに向き合うことと言えよ う。臨床家が EBM の知識に加えて, SDM の意識 を持って，患者と力を合わせることができれば，工 ビデンスを活用することで臨床的な不確実性を減ら し，それでも不可避的に残る不確実な現実自体は変 えられなくても，それに向き合う人間の力を変えて いけるだろう。

Whitney ら ${ }^{9)}$ は医療行為の確実性と生命へのリス クの 2 軸で，臨床場面を 4 つに分け，それぞれに適 する意思決定・合意形成の方法を提示している。こ こでは不確実性が高く, 生命のリスクが大きい領域 として「早期乳がんの患者に対する拡大乳房切除術 又は乳房温存術十放射線治療の選択肢」，直近の生 命のリスクは高くないが，不確実性の高い領域で は，「中等度の高コレステロール血症の男性に対す る生活習慣の修正の徹底又はコレステロール降下薬 の服用の選択肢」が挙げられている. SDM はこの ような状況で特に必要とされる。一方，確実性が高 い（う最良の選択肢が $1 つ ）$ 状況として「腹部銃創 患者に対する外科療法」,「低カリウム血症の患者に おける利尿薬の減量」が示されている。これらの状 況では SDM ではなく通常の IC か，簡潔な情報提 供によるシンプル・コンセントが適切となる，以上 から分かるように，すべての診療場面で IC から $\mathrm{SDM}$ への転換が必須とされているのではない，患 者の状態を適切に評価し，その時点で利用可能な工 ビデンスを十分把握した上で，その状況の確実性・ 
不確実性を理解し，どのような意思決定・合意形成 を行うことが最良か判断できる能力がこれからの医 療者に求められる要件となるだろう。

\section{SDM がなければ EBM はどうなるか ?}

EBM の実践では，治療の選択肢，益と害，患者 の価值観を共有して意思決定を行うSDM は本来切 り離せない。しかしながら，医療者が治療やその工 ビデンスのみを一方的に患者に提示し，患者の理解 や希望を尊重せずに，提供した情報への了承を求め ていることも少なくない，EBM に熱心な医療者は 臨床研究による一般論としてのエビデンスに常に最 も重きを置こうとするかもしれないが，EBM の定 義に基づけば，エビデンスは「意思決定のための重 要な一要素」であり, エビデンス以外の要因も考慮 した総合的な判断が本来の目指すところである。臨 床研究による一般論としてのエビデンスは，患者に とつて（医療者以上に）選択の 1 つの手がかりに留 まる場合もあるだろう。患者は，臨床的なアウトカ ムのわずかな改善よりも，入院の必要性や副作用の リスク，医療費のように，その治療を受けることの 負担，そして自分自身の社会的な役割や自尊感情， アイデンティティ，又は家族との関係性を重視する かもしれない. 2014 年にオーストラリアの臨床疫 学者 Hoffman が JAMA 誌に発表した論考で指摘し た「SDM がなければ EBM はエビデンスによる圧 政（evidence tyranny）に転ずる」という警鐘を医 療者は自戒を以って傾聴すべきであろう。10) Hoffman は最適な患者ケアの実現には，EBM と患 者を尊重するコミュニケーションの合流点で SDM が行われることの重要性を強調している.

\section{SDM を進めるための診療ガイドライン}

国内における診療ガイドラインに関する情報セン ターである公益財団法人日本医療機能評価機構 Mindsでは, 診療ガイドラインを「診療上の重要度 の高い医療行為について，エビデンスのシステマ ティックレビューとその総体評価, 益と害のバラン スなどを考慮し，最善の患者アウトカムを目指した 推奨（recommendation）を提示することで，患者 と医療者の意思決定を支援する文書」と定義してい る. ${ }^{11)}$ 診療ガイドラインは，その定義にあるように 医療者のみならず患者の意思決定も支援する役割を 担う。しかし，その診療ガイドラインが患者の視点 を反映していないものであれば，患者の支援は可能
であろうか？ 診療ガイドライン評価として現在最 も使用されているものが Appraisal of Guideline Research and Evaluation (AGREE) 共同計画が作 成した AGREE II であり，6 領域 23 の評価項目が ある. ${ }^{12)}$ その中の項目 5 は「患者の視点や希望が考 慮されたか」を尋ねるもので，診療ガイドラインに おける患者参加の重要性が窥える.

診療ガイドラインの推奨はあくまで一般論であ り，その疾患の患者の約 60-95\%に適用できるもの とされている. ${ }^{13)}$ 推奨の決定過程に患者の価值観や 意見が反映されていれば，個々の臨床現場で，医療 者だけでなく，診療ガイドラインは臨床の場で患者 の意思決定にも役立つものになるだろう．近年の診 療ガイドライン作成では, ${ }^{14-16)}$ 核心である推奨の決 定要因として，「重大なアウトカムに関するエビデ ンス総体の質・確実性」，「益（望ましい効果）と害 (望ましくない効果) のバランス」，「患者の価值観・ 希望の多様性」，「コストや利用可能な資源」が重視 され，専門医に偏らず，関係する様々な医療職や患 者自身も参加する学際的なガイドラインパネルによ る総意形成の必要性が強調されている.

\section{6. 結び}

SDM の過程は双方向的で，相互作用を持つもの であり，医療者が相手を「自分に合わせるように変 えていく（医療者が提示した方針に患者が同意す る)」ことではなく，医療者と患者が「ともに変 わつていく」過程が意味を持つ。結果として医療者 が提示した治療方針が選ばれたとしても，その過程 は IC と大きく異なるＩICでは「同意した・しない」 の結果が重視されるのに対し，SDM では一旦成立 した患者と医療者の間の合意の内容自体が，時間の 経過とともに変化することも十分あり得るものと考 える，すなわち SDM で重視されることは，「同意 した・しない」という固定された結果ではなく，患 者と医療者が共有する過程それ自体と両者の関係性 の構築であると言える.

臨床の場で適切な薬物療法が実施されるには, 医 療者と患者，家族・支援者の間でエビデンスに基づ くコミュニケーション，医薬品のベネフィットとリ スクをめぐる情報のやり取りが必要となる。しかし 医療行為のベネフィットとリスクのエビデンスは, 人間を対象とする臨床研究の持つ数々の限界と, 人 間の多様性・個別性のため，無視できない，そして 
避けることのできない不確実性に常に包まれてい る. ${ }^{17)} こ の$ 不確実性に向き合い，その中で納得のい く意思決定を行っていくための人間の知恵の 1 つが SDM と言えるかもしれない.

医薬品のベネフィットとリスクの臨床的エビデン スの推進とともに，医療者と患者の意思決定と合意 形成，そして新たな関係づくりに向けて SDM の議 論が進むことを願い本稿の結びとする.

利益相反 筆者は大塚製薬株式会社・大日本住 友製薬株式会社の学術アドバイザーである．株式会 社日本医療データセンターより奨学寄附金を受けて いる．株式会社イービーヘルスより受託研究費を受 けている。ファイザー株式会社，MSD 株式会社， 中外製薬株式会社，日本ベーリンガーインゲルハイ ム株式会社，ノボノルディスクファーマ株式会社 より講演謝金を受けている.

\section{REFERENCES}

1) Guyatt G., ACP J. Club, 114, A16 (1991).

2) Straus S. E., Glasziou P., Richardson W. S., Haynes R. B., "Evidence-Based Medicine: How to Practice and Teach It," 4th ed., Churchill Livingstone, London, 2010.

3) Sackett D. L., Rosenberg W. M., Gray J. A., Haynes R. B., Richardson W. S., BMJ, 312, 71-72 (1996).

4) Barry M. J., N. Engl. J. Med., 366, 780-781 (2012).

5) Fujimoto S., Kon N., Nakayama T., Japanese Medical Journal, 4825, 20-22 (2016).

6) Charles C., Gafni A., Whelan T., Soc. Sci. Med., 44, 681-692 (1997).
7) Godolphin W., BMJ, 327, 692-693 (2003).

8) “Shared Decision Making," ed. by Nakayama T., Ijishimposha, Tokyo, 2017.

9) Whitney S. N., McGuire A. L., McCullough L. B., Ann. Intern. Med., 140, 54-59 (2004).

10) Hoffmann T. C., Montori V. M., Del Mar C., $J A M A$, 312, 1295-1296 (2014).

11) "Minds 2014 Guidebook of Development of Clinical Practice Guidelines," ed. by Fukui T., Yamaguchi N., Igaku-Shoin Ltd., Tokyo, 2014

12) AGREE Next Steps Consortium, "The AGREE II Instrument,” 2009: 〈http://www.agreetrust. org $\rangle$, cited July 31, 2017.

13) Eddy D. M., JAMA, 263, 3077, 3081, 3084 (1990).

14) Guyatt G. H., Oxman A. D., Vist G. E., Kunz R., Falck-Ytter Y., Alonso-Coello P., Schünemann H. J., GRADE Working Group, BMJ, 336, 924-926 (2008) .

15) Guyatt G. H., Oxman A. D., Kunz R., FalckYtter Y., Vist G. E., Liberati A., Schünemann H. J., GRADE Working Group, BMJ, 336, 1049-1051 (2008).

16) Institute of Medicine, "Clinical Practice Guidelines We Can Trust," National Academy Press, Washington DC, 2011.

17) US Department of Health and Human Services, Food and Drug Administration (FDA), Risk Communication Advisory Committee and consaltants, "Communicating Risks and Benefits: An Evidence-Based User's Guide," ed. by Fischhoff B., Brewer N. T., Downs J. S., US Department of Health and Human Services, FDA, Silver Spring, 2011. 